\title{
COMPUTER SELF-EFFICACY REVISITED
}

\author{
Elizabeth A. Loar, Grand Canyon University
}

\begin{abstract}
Computer self-efficacy is associated with a variety of positive learning processes and outcomes. Despite historical attempts to measure computer self-efficacy, there are severe validity concerns apparent in the literature. In 2014, M. C. Howard developed the Computer Self-Efficacy Scale (CSES) with a focus on general computer use rather than reliance on specific technological hardware. The two studies here employed a nonexperimental, quantitative research design with self-report measures. The majority of participants in this study were female students from a Midwestern community college. In Study 1, the reliability and divergent validity of the CSES was tested. In Study 2, the unidimensional factor structure of the measure was supported through confirmatory factor analysis. The findings show additional evidence for the reliability and validity of the CSES with community college participants from the Midwest United States. Based on the results of this research, instructors and researchers may administer the CSES for general assessment and research purposes with reasonable confidence.

Keywords: computer self-efficacy, community college students, factor analysis

\section{COMPUTER SELF-EFFICACY REVISITED}

Although the use of technology improves student learning and motivation (Ciampa, 2014), relying on online learning environments alone likely will not lead to better grades (Rosen, Carrier, \& Cheever, 2013). Computer self-efficacy has been associated with training effectiveness (Chien, 2012), intensions to use computers, their perceived ease of use (Hsia, Chang, \& Tseng, 2014), and test performance (Hauser, Paul, Bradley, \& Jeffrey, 2012). Although the growth rate of online learning systems is astounding, the lack of research on individual differences affecting users' adoption of online learning is problematic. Bandura (2016) pointed out that as technologies and informational changes continue, personal efficacy is an essential topic for study. Researchers developed the concept of computer self-efficacy as a specific application of Bandura's (1986) concept of self-efficacy. Karsten, Mitra, and Schmidt (2012) define computer selfefficacy as "an individual's perception of efficacy in performing specific computer related tasks within the domain of general computing" (p. 54).

\section{HISTORY OF COMPUTER SELF-EFFICACY MEASUREMENT}

Early measures of computer self-efficacy first stemmed from the acceptance and availability of computers in the 1980s. Murphy, Coover, and Owen (1989) published one of the first measures of computer self-efficacy, which focused on mainframe computer skills. Researchers criticized the measurement tools of the 1980s because they referred to developed skills rather than envisioned capabilities. Other measures became quickly outdated because they contained references to outdated software programs such as WordPerfect (Compeau \& Higgins, 1995).

Cassidy and Eachus (2002) developed the Computer User Self-Efficacy scale, which contained the item, "DOS-based computer packages don't cause many problems for me." Conrad and Munro (2008) noted the irony of assessing self-efficacious beliefs with outdated measurement tools, although their now-antiquated Computer Technology Use Scale referenced VCRs, CDs, and video recorders. Howard (2014) asserted that many computer selfefficacy measurement instruments are not only
\end{abstract}


outdated but lacked psychometric properties. Chiu and Wang (2008) studied both self-regulation and computer self-efficacy in their study and utilized items from eight different authors.

Regardless of the validity issues with past computer self-efficacy measurement tools, researchers envisioned theoretical applications and the future usefulness of such developments. Cassidy and Eachus (2002) envisioned computer self-efficacy measurement instruments as tools to identify students with low computer self-efficacy who may face motivational obstacles and negative perceptions of control in their learning environment. Compeau and Higgins (1995) asserted that low levels of computer self-efficacy are associated with high levels of anxiety and stress, which ultimately leads to a decline in performance.

\section{VALIDITY CONCERNS}

Constructs relating to computer-self efficacy are often used interchangeably in the literature. For instance, Sun and Rueda (2012) investigated relationships among motivational and engagement variables for participants enrolled in online courses in gerontology and engineering at a university in Southwestern United States. Internet self-efficacy was the overall construct measured by the Web Users Self-Efficacy Scale (Eachus \& Cassidy, 2006), although Sun and Rueda operationally defined the construct as computer self-efficacy in their study. An example item contained in the Internet Technology subscale is, "I am not really sure what a modemdoes." Sun and Rueda concluded that computer self-efficacy had no direct effect on student engagement, which is not surprising considering the measurement tool utilized for the study.

Convergent validity is also a concern with computer self-efficacy measurement tools. Wang, Shannon, and Ross (2013) researched the relationships among 2,139 college students' selfregulated learning, and their characteristics, course outcomes, and technology self-efficacy in online learning courses, and they concluded that when students had higher levels of motivation in their online courses, their levels of technology self-efficacy and course satisfaction increased. The Online Technology Self-Efficacy Scale (Miltiadou \& Yu, 2000) utilized in Wang et al.'s study referenced online learning activities such as opening a browser, replying to a message board, and using email with four subscales. A sample item from the Internet Competencies subscale is, "I would feel confident bookmarking a website." As noted by Wang et al. (2013), their results were not in agreement with Puzziferro's (2008) findings. Puzziferro measured online technologies selfefficacy with an instrument validated with four separate scales but found them to be unreliable and combined the items into a single construct. Wang et al. concluded that students with higher levels of technology self-efficacy tended to receive better grades. Wang et al. concluded that "based on this study, the technology self-efficacy included two different dimensions, general computer selfefficacy, and online learning platform-related selfefficacy. This suggests that students who want to succeed in online learning should have confidence in general computer skills as well as in using online learning platforms" (p. 317). Wang et al. made no other mention of computer self-efficacy within the article. The Online Technology Self-Efficacy Scale measure itself, divided into four separate scales, clearly referenced online computing skills.

Ironically, computer self-efficacy has not reached full research potential (Howard, 2014) as envisioned by early investigators. Howard created the Computer Self-Efficacy Scale (CSES) with ever-changing technologies in mind, evidenced by general terms such as "computers" contained within items that reference technology. Howard noted that "scale validation is never complete . . . the new computer self-efficacy measure can be validated beyond those within the current study" (p. 680).

\section{COMPUTER SELF-EFFICACY SCALE}

Scores on the 12-item CSES indicate participants' feelings towards their capabilities in working with a laptop or desktop computer. Items include statements such as, "I am a selfreliant person when it comes to doing things on a computer," and "I can remain calm when facing computer difficulties because I can rely on my abilities." Throughout the development of the new measure, Howard (2014) measured several aspects of reliability and validity. Confirmatory factor analysis resulted in the final 12-item measure $(\alpha=$ .95). In order to gauge criterion validity, Compeau and Higgins' (1995) Computer Efficacy Scale was 
Table 1. Study 1 Correlation Matrix

\begin{tabular}{|l|l|l|l|l|l|}
\hline & $\mathbf{1}$ & $\mathbf{2}$ & $\mathbf{3}$ & $\mathbf{M}$ & SD \\
\hline $\begin{array}{l}\text { Computer Self- } \\
\text { Efficacy }\end{array}$ & & & & 5.31 & .99 \\
\hline $\begin{array}{l}\text { Intrinsic Goal } \\
\text { Orientation }\end{array}$ & $.34^{* * *}$ & & & 5.18 & .95 \\
\hline Effort Regulation & $.19^{\star}$ & $.38^{* * *}$ & & 6.07 & .78 \\
\hline
\end{tabular}

Note: $\mathrm{M}=$ Mean, $\mathrm{SD}=$ Standard Deviation, $\mathrm{N}=152{ }^{*} \mathrm{p}<.05,{ }^{* * *} \mathrm{p}<.001$

Table 2. Confirmatory Factor Analysis Fit Indices for Computer Self-Efficacy Scale

\begin{tabular}{|l|l|l|l|l|l|l|l|}
\hline & \multicolumn{2}{|c|}{ CFI } & \multicolumn{1}{c|}{ GFI } & \multicolumn{2}{c|}{ NFI } & RMSEA & \multicolumn{2}{c|}{ AIC } & \multicolumn{2}{c|}{ df } & df \\
\hline Howard's CFA & .98 & .95 & .96 & .09 & 143 & 95 & 54 \\
\hline Current Study & .94 & .88 & .90 & .05 & 171 & 123 & 54 \\
\hline
\end{tabular}

administered $(r=.43)$. Convergent validity was assessed using Chen, Gully, and Eden's (2001) eight-item measure of general self-efficacy $(r=$ $.38)$.

\section{STUDY 1}

The purpose of Study 1 was to assess reliability and validity estimates of the CSES. The sample consisted of $N=152$ students who were enrolled in online psychology courses at a Midwestern community college. Most of the participants who completed the survey were female $(80.9 \%)$ and over half of the participants (55.7\%) were ages 19-25 $(M=27.36, S D=9.05)$. Most participants (69.1\%) indicated they were taking the psychology course because it was required for their major or fulfilled elective requirements.

Two instruments were administered to the sample to assess the psychometric properties of the CSES. Data were cleaned and determined to be appropriate for analysis with normal distributions. The reliability estimate for the CSES was high, as expected $(\alpha=.93)$. Two self-regulation constructs, intrinsic goal orientation and effort regulation, were measured through the Motivated Strategies for Learning Questionnaire (Pintrich, Smith, García, \& McKeachie, 1991) as indicators of divergent validity. See Table 1 for correlations. The bivariate correlation between effort regulation and computer self-efficacy was $r=.185(p<.05)$. The bivariate correlation between intrinsic goal orientation and computer self-efficacy was $r=.340(p<.001)$. The constructs of intrinsic goal orientation and effort regulation are related to computer self-efficacy but not so strongly that they are not differentiated.

\section{STUDY 2}

The purpose of Study 2 was to assess the CSES as a single factor, as originally designed, using confirmatory factor analysis. Data obtained from Study 1 was utilized for analyses in Study 2. Analyses considered exploratory in nature allowed for examination of specific qualities of the onefactor model fit. Using the maximum likelihood in SPSS, one factor was extracted. Correlates within the one-factor model were outstanding but not greater than .8 , which would be problematic. The KMO value was high at .93. One item loaded comparatively low, but the model was not improved with removal. The one-factor confirmatory factor analysis was computed using AMOS.

The resulting fit indices are comparable to the confirmatory analysis conducted by Howard (2014) (see Table 2). RMSEA tries to correct for both the model complexity and sample size by including each in its computation, where lower values indicate a better fit. The RMSEA indices suggested that the one-factor model fit the obtained data adequately. The measurement model achieved CFI and NFI indices of at least .90, which represents 
good fit (Hair, Black, Babin, \& Anderson, 2010). GFI values of .90-.95 are considered good.

\section{DISCUSSION}

The current study employed a nonexperimental, quantitative research design with self-report measures. The majority of participants in this study were female students from a Midwestern community college. Higher perceptions of computer self-efficacy have been positively associated with a variety of desired outcomes, including high test performance (Hauser et al., 2012) and enhanced training effectiveness (Chien, 2012). The theoretical model underlying computer self-efficacy was confirmed through confirmatory factor analysis. This extended the research on the psychometric properties of Howard's (2014) CSES with community college participants from a Midwestern region of the United States.

\section{CONCLUSION}

A good fit was found for the structure of the CSES and it can be concluded that the items measured computer self-efficacy as postulated by Howard.Instructors and researchers may administer the CSES for general assessment and research purposes with reasonable confidence based on the results of the current study, but they must exercise caution in the interpretation and generalization of results to other populations. Future researchers may consider conducting studies that include online and campus-based students in multiple disciplines to obtain diverse samples. Learning outcomes such as performance measures could provide a foundation for future validation research. 


\section{REFERENCES}

Bandura, A. (1986). Social foundations of thought and action: A social cognitive theory. Englewood Cliffs, NJ: Prentice-Hall.

Bandura, A. (2016). Moral disengagement. New York, NY: Worth Publishers.

Cassidy, S., \& Eachus, P. (2002). Developing the computer user self-efficacy (CUSE) scale: Investigating the relationship between computer self-efficacy, gender and experience with computers. Journal of Educational Computing Research, 26(2), 133-153. doi:10.2190/jgjr-0kvl-hrf7-gcnv

Chen, G., Gully, S. M., \& Eden, D. (2001). Validation of a new general self-efficacy scale. Organizational Research Methods, 4(1), 62-83. doi:10.1177/109442810141004

Chien, T. (2012). Computer self-efficacy and factors influencing e-learning effectiveness. European Journal of Training and Development, 36(7), 670-686. doi:10.1108/03090591211255539

Chiu, C. M., \& Wang, E. T. (2008). Understanding Web-based learning continuance intention: The role of subjective task value. Information \& Management, 45(3), 194-201. doi:10.1016/j.im.2008.02.003

Ciampa, K. (2014). Learning in a mobile age: An investigation of student motivation. Journal of Computer Assisted Learning, 30(1), 82-96. doi:10.1111/jca1.12036

Compeau, D. R., \& Higgins, C. A. (1995). Computer self-efficacy: Development of a measure and initial test. MIS Quarterly, 19(2), 189-211. doi:10.2307/249688

Conrad, A. M., \& Munro, D. (2008). Relationships between computer self-efficacy, technology, attitudes and anxiety: Development of the Computer Technology Use Scale (CTUS). Journal of Educational Computing Research, 39(1), 51-73. doi:10.2190/ec.39.1.d

Eachus, P., \& Cassidy, S. (2006). Development of the Web Users Self-Efficacy scale (WUSE). Issues in Informing Science and Information Technology Journal, 3, 199-209. doi:10.28945/883

Hair, J. F., Black, W. C., Babin, B. J., \& Anderson, R. E. (2010). Multivariate data analysis: A global perspective (7th ed.). Upper Saddle River, NJ: Pearson.

Hauser, R., Paul, R., Bradley, J., \& Jeffrey, L. (2012). Computer self-efficacy, anxiety, and learning in online versus face to face medium. Journal of Information Technology Education: Research, 11, 141-154. doi:10.28945/1633
Howard, M. C. (2014). Creation of a computer self-efficacy measure: Analysis of internal consistency, psychometric properties, and validity. Cyberpsychology, Behavior and Social Networking, 17(10), 677-681. doi:10.1089/ cyber.2014.0255

Hsia, J., Chang, C., \& Tseng, A. (2014). Effects of individuals' locus of control and computer self-efficacy on their e-learning acceptance in high-tech companies. Behaviour \& Information Technology, 33(1), 51-64. doi:10.1080 /0144929X.2012.702284

Karsten, R., Mitra, A., \& Schmidt, D. (2012). Computer selfefficacy: A meta-analysis. Journal of Organizational and End User Computing, 24(4), 54. doi:10.4018/joeuc.2012100104

Miltiadou, M., \& Yu, C. H. (2000). Validation of the Online Technologies Self-Efficacy Scale (OTSES). Retrieved from ERIC database (ED445672).

Murphy, C. A., Coover, D., \& Owen, S. V. (1989). Development and validation of the Computer Self-Efficacy Scale. Educational and Psychological Measurement, 49(4), 893-899. doi:10.1177/001316448904900412

Pintrich, P. R., Smith, D. F., García, T., \& McKeachie, W. J. (1991). A manual for the use of the Motivated Strategies Questionnaire (MSLQ). Ann Arbor, Ml: University of Michigan, National Center for Research to Improve Postsecondary Teaching and Learning.

Puzziferro, M. (2008). Online technologies self-efficacy and self-regulated learning as predictors of final grade and satisfaction in college-level online courses. The American Journal of Distance Education, 22(2), 72-89. doi:10.1080 108923640802039024

Rosen, L. D., Carrier, L. M., \& Cheever, N. A. (2013). Facebook and texting made me do it: Media-induced task-switching while studying. Computers in Human Behavior, 29(3), 948-958. doi:10.1016/j.chb.2012.12.001

Sun, J. C.-Y., \& Rueda, R. (2012). Situational interest, computer self-efficacy and self-regulation: Their impact on student engagement in distance education. British Journal of Educational Technology, 43(2), 191-204. doi:10.1111/j.14678535.2010.01157.x

Wang, C., Shannon, D. M., \& Ross, M. E. (2013). Students' characteristics, self-regulated learning, technology self-efficacy, and course outcomes in online learning. Distance Education, 34(3), 302-323. doi:10.1080 /01587919.2013.835779 